\title{
Küresel Edebiyat Eğilimi Bağlamında Milenyum Sonrası Dönemdeki Nobel Edebiyat Ödülleri
}

\section{Post-Millennium Nobel Literature Prizes in the Context of Global Literary Trends}

\author{
Fethi Demir ${ }^{1}$ (D), Nahide Ece Süslü² (D)
}

${ }^{1}$ Doç. Dr., Van Yüzüncü Yıll Üniversitesi, Eğitim Fakültesi, Van, Türkiye

${ }^{2}$ Yüksek Lisans Öğrencisi, Van Yüzüncü Y1l Üniversitesi, Eğitim Bilimleri Enstitüsü, Türk Dili ve Edebiyatı Anabilim Dalı, Van, Türkiye

ORCID: F.D. 0000-0002-1855-0460; N.E.S. 0000-0001-8456-883X

Sorumlu yazar/Corresponding author: Fethi Demir,

Van Yüzüncü Y1l Üniversitesi, Eğitim Fakültesi, Türk Dili ve Edebiyatı Eğitimi Bölümü, Zeve

Kampüsü, Van, Türkiye

E-mail: mfethi_demir@yahoo.com

Başvuru/Submitted: 28.01 .2021

Revizyon Talebi/Revision Requested: 26.03.202 Son Revizyon/Last Revision Received: 09.04.2021 Kabul/Accepted: 19.04.2021

Atıf/Citation:

Demir, F., \& Suslu, N. E. (2021). Küresel edebiyat eğilimi bağlamında milenyum sonrası dönemdeki nobel edebiyat ödülleri. TUDED, 61(1), 103-121.

https://doi.org/10.26650/TUDED2021-869869

\section{ÖZET}

Küreselleşmenin yoğun bir biçimde etkilediği sanatların başında edebiyat gelmektedir. Edebiyat, dil aracılı̆̆ıyla yüzyıllar boyunca ulusal kültürün inşasında önemli rol oynamıştır. Bugün ise büyük oranda, ulusal olanı aşmanın ve küresel boyuta geçmenin aracıdır. Teknolojinin özellikle son yarım asırdaki gelişimi, dijitalleşme, çeviri imkânlarının ve yayımlanma tekniklerinin baş döndürücü bir hızla ilerlemesi, edebiyatı sadece ulusal sınırların içerisinde konumlandıran paradigmayı sarsmıștır. Goethe'nin 19. yüzyılın ilk yarısında ortaya attığı "Dünya Edebiyatı" kavramı, onun öngörülerinin ötesine geçmiştir. Özellikle Milenyum ile birlikte bu kavram, "Küresel Edebiyat"a dönüşmüştür. Bu gerçekliğin kendini en somut biçimde gösterdiği yer ise Nobel Edebiyat Ödülü'dür. Dünyanın bu en prestijli edebiyat ödülü verilirken ulusal edebiyatların öne çıkan kalemlerinden çok, uluslararası platformda yer edinebilmiş edebiyatçıların tercih edildiği gözlemlenmektedir. Nitekim 2000'li yıllarla birlikte Nobel Edebiyat Ödülü, dünya edebiyatının genel geçer yasalarını daha fazla belirlemekte, sanatçılar ve eserler için uluslararası edebiyat ağına eklemlenmenin imkânlarını sunmaktadır. Bu çalışmada; 2000-2020 döneminde Nobel Edebiyat Ödülü’nü kazanan sanatçıların ödülü alma nedenleri, cinsiyetleri, ülkeleri, eserlerinin dili, türü ve içerik özellikleri bağlamında betimsel analiz yapılmıştır. Nobel Edebiyat Ödülü’nün 2000'den sonraki dağılımı ile küresel edebiyat teorisi arasında korelasyon tespit edilmeye çalışılmıştır. Betimsel analiz sonucunda; Milenyum öncesi döneme göre kadın edebiyatçı sayısının arttı̆̆ı, eserlerin dilinin çoğunlukla İngilizce, Fransızca ve Almanca olduğu, roman türünün başat olarak ön plana çıktığı görülmüştür.

Anahtar Kelimeler: Milenyum sonrası, Nobel Edebiyat Ödülü, küresel edebiyat, dünya edebiyatı, küreselleşme

\begin{abstract}
Globalization has intensely affected the leading art of literature that has, for centuries, deployed languages to discharge a pivotal role in the construction of national cultures. Currently, literature is a means of transcending the national to achieve a global dimension. The development of technology, especially in the last half-century, has enabled digitalization, made translation possible at a dizzying pace, and introduced publishing techniques. These advances have shaken the paradigm that only positions literature within the ambit of national borders. Goethe's conception of Weltliteratur in the first half of the $19^{\text {th }}$ century has surpassed his predictions. In particular, the concept has been transmogrified into "global literature" in the current millennium. This reality is most explicitly manifested in the Nobel Prize for literature. The awarding of this
\end{abstract}




\begin{abstract}
most prestigious prize elucidates the preference for literary texts that can achieve recognition in the international arena over prominent works that remain within the scope of national literature. In fact, the Nobel Prizes awarded for literature in the 2000s are increasingly determined by the rules of Weltliteratur, offering opportunities for diverse artists and works to be articulated into international literary networks. This study performed a descriptive analysis of the reasons, genders, countries, languages, genres, and content-related attributes of the artists awarded with the Nobel Prize for literature in the period spanning 20002020. The study also attempted to determine the correlations between global literary theory and the post-2000 Nobel Prize awards for literature. The outcomes of the descriptive analysis elucidated that the number of awarded women writers increased in comparison to the period preceding this millennium. The awarded oeuvres were primarily created in English, French, and German, and the awards predominantly represented the genre of the novel.
\end{abstract}

Keywords: Post-millennium, Nobel Prize for literature, global literature, Weltliteratur, globalization

\title{
EXTENDED ABSTRACT
}

Globalization has intensely affected the leading art of literature that has, for centuries, deployed languages to discharge a pivotal role in the construction of national cultures. Currently, literature is a means of transcending the national to achieve a global dimension. The development of technology, especially in the last half-century, has enabled digitalization, made translation possible at a dizzying pace, and introduced publishing techniques. These advances have shaken the paradigm that only positions literature within the ambit of national borders. The interactions between stakeholders of the literary world have naturally increased because they can now meet within short durations as literature is produced across the globe in almost every country and language. Thus, a global atmosphere is made available to both authors and readers, radically transforming the content, format, and publishing techniques of texts. Goethe's conception of Weltliteratur in the first half of the 19th century has surpassed his predictions. In particular, the concept has been transmogrified into "global literature" in the current millennium and has become the fundamental notion of the art and culture industry. This reality is most explicitly manifested in the Nobel Prize for literature.

The Nobel Prize has been awarded for many disciplines since the beginning of the 20th century. Despite numerous debates, it is generally regarded as the most prestigious literary award in the world. The awarding of the Nobel Prize after 2000 has generally coincided with trends in global literature. The preference for literati who can claim a place in the international arena is evident over authors prominent in their national literature. Such internationally accessible intellectuals tackle issues that concern all humanity from a universal perspective. They are distanced from ideological bigotry and utilize a moderate, synthesist, and conciliatory style. It is also apparent that such writers live like global citizens and pioneer new literary eras.

This study performed a descriptive analysis of the reasons, genders, countries, languages, genres, and content-related attributes and variables pertaining to writers awarded with the Nobel Prize for literature in the period spanning 2000-2020. The study also attempted to determine the correlations between global literary theory and the post-2000 Nobel Prize awards for literature. Descriptive analysis techniques were deployed for the assessments. 
The descriptive analysis of the collected data revealed that $7(33 \%)$ female writers were awarded the Nobel Prize for literature in the last 21 years. Before the beginning of this century, $10 \%$ of the Nobel awardees for literature were female; this figure rose to $33 \%$ in the current millennium. This increase may be attributed to the general strengthening of the presence of women in all walks of life. That universal themes such as feminism and women's rights now form a crucial aspect of global literary awareness could also have contributed to the increased recognition of women by the Nobel committee. It was determined that the awarded writers wrote mainly in English, French, and German. The issue of genre is also an essential intersection node for the literary Nobel and global literary trends. The genres of work represented by the awardees included 16 (76\%) novels, 3 (14\%) poems, 1 (5\%) story, and 1 (5\%) play. Goethe, posited the idea of Weltiteratur, described poetry as the "universal property of humanity." However, the genre of poetry must yield to the novel in the process of the globalization of literature. Poetry is confronted with several obstacles in global literature because it must appeal to emotions and intensively encompasses images and metaphors that may not be universally available. The nature of the 21 st century is information/informatics, which holds the mind/ thinking at the forefront. The relativity and variability of knowledge have also contributed to the novel becoming the dominant genre of contemporary literature.

Undoubtedly, the recent transformations in technology, transportation, social lives, and economic activities have been pivotal in the evolution of the notion of Weltliteratur to global literature. Literature has been restructured through transnational knowledge, and the Nobel Prize for literature is a palpable indicator of such worldwide familiarity. Any analysis of the dialectical relationship between the Nobel Prize for literature and global literary understanding must make sense of and examine the literary and cultural milieux of the future. An international prize of the stature of the Nobel awarded in the context of global literary trends can only be comprehensively grasped through the argument of global literary appreciation. 


\section{Giriş}

Edebiyat; duyguların, arzuların, hayallerin, düşüncelerin dil aracılığıyla sözlü, yazılı, dijital olarak belirli formlar ve estetik kaygılar bağlamında üretildiği bir sanattır. İnsanlık tarihiyle yaşıt bir geleneğe sahip olan edebiyat, aynı zamanda medeniyet tarihinin kurucu, taşıyıcı ve dönüştürücü unsurlarının da başında gelmektedir. Diyalektik bir biçimde hem insanlığın gelişimine rehberlik etmekte hem de ortaya çıkan her dönüşümden etkilenmektedir. Bu bağlamda edebiyatın tarihi açısından üç önemli aşamadan bahsedilebilir. Bunlardan ilki yazının icadıdır; sözlü edebiyatın yerini yazılı edebiyatın alması anlamına gelir. İkincisi matbaanın icadıdır; bu da yazılı edebiyatın çoğaltılmasını, zamansal ve mekânsal anlamda yaygınlaşmasını, muhafaza edilmesini sağlar. Üçüncüsü ise Enformasyon Çağı ile birlikte dijital bir ortama taşınması, küresel etkileşime açık bir boyuta evirilmesidir; bu da küresel edebiyat çağına tekabül eder. Elbette, tüm bu kırılma noktaları edebiyatın tüm paydaşları açısından da tarihî bir dönüşümün habercisidir. Edebiyatçı da edebiyat eseri de okur da yayımlanma teknikleri de bu dönüşümlerden nasibini alır. Özcesi sözlü edebiyat dönemi yerel/mahalli evre, yazılı edebiyat dönemi ulusal evre, dijitalleşme dönemi ise küresel evre olarak tasnif edilebilir. Bu bağlamda çalışmanın esasını oluşturan edebiyatın küresel evresine daha ayrıntılı bakılabilir.

Makalenin amacı, Milenyum'dan sonra verilen Nobel Edebiyat Ödülleri'nin dağılımında küresel edebiyat eğiliminin/algısının öne çıktığını ispatlamaya çalışmaktır. Başka bir ifadeyle içinde yaşadığımız küresel çağın, kültürün her alanına olduğu gibi edebiyata da etki ettiğini göstermektir. Öyle ki edebiyat ile küreselleşme arasındaki karmaşık bağlantılılık (complex connectivity) diyebileceğimiz ilişkiye dikkat çekmektir. Çünkü günümüzde, sadece edebiyatta değil; kültür çalışmalarının her alanında "küreselleşmenin işaret ettiği dönüştürücü süreçler anlaşılmadan kapsamlı ve doğru analizlerin yapılamayacağı aşikârdır.” (Tomlinson, 2017, s. 12) Modern dünyada edebiyatın, sanatın ve kültürün hangi yönsemeler içerisinde olduğunu anlamının yolu küreselleşmenin ortaya çıkardığı durumlarla ilgilidir. Edebiyat açısından küreselleşmenin izlerini sürebileceğimiz en uygun alan ise hiç kuşkusuz Nobel Edebiyat Ödülleri'dir. Bu hipotezi kanıtlamak amacıyla Nobel Vakfının yapısına, ödülü verme ölçütlerine değinilmiştir. Bu yapı ve ölçütler çözümlendikten sonra 20 yıllık periyotta (2000-2020) Nobel Edebiyat Ödülü’nün dağılımı çeşitli kriterlere göre tasnif edilip sonrasında da bu verilerin küresel edebiyat eğilimi ile ilişkisi saptanmaya çalışılmıştır. Bu bağlamda betimsel araştırma yöntemine dayanan nitel bir araştırma ve içerik analizi yapılmıştır. Nitekim nitel araştırma, “Gözlem, görüşme ve doküman analizi gibi nitel bilgi toplama yöntemlerinin kullanıldığı, algıların ve olayların doğal ortamda gerçekçi ve bütüncül bir biçimde ortaya konmasına yönelik nitel bir sürecin izlendiği araştırmadır.” (Yıldırım, 2016, s. 10). Özcesi çalışmamızda, Milenyum sonrası edebiyat atmosferine egemen olan küresel edebiyat eğiliminin etkisini betimlemek için, 2000-2020 yılları arasında verilen Nobel Edebiyat Ödülleri, çeşitli değişskenlere (ödülün veriliş nedeni, yazarın cinsiyeti, ülkesi, kıtası, eserin dili ve türü) göre incelenmiştir.

Her şeyden önce küresel edebiyat, kapitalizmin uluslararası bir hâl aldığı yakın dönemin bir eğilimi olmakla birlikte Goethe'nin ortaya attığ 1 "Weltliteratur” yani “dünya edebiyatı" kavramına 
uzanan bir arka plana sahiptir. Goethe, 1827 yılında, fen ve botanik gibi alanlardaki bilimsel çalışmalardan etkilenerek ulusal edebiyatların ötesinde bir “dünya edebiyatı" kavramından bahsetmiştir. Bu kavram, kolektif bir edebî dünyanın karşılığıdır; herhangi bir dilin veya ulusun tekelinde olmayan ideadır. Goethe'nin bu ideasının inşasında şüphesiz insanlığın arketipsel birliği vardır. Varoluştan bu yana insanlığın hafızası birbirine benzer anlatılar üretmiştir. Farklı coğrafyalardan ya da kültürel bağlamlardan da üretilmiş olsalar içerik ve biçim benzerlikleri ile özellikle nitelikli edebî eserlerin birbirini besleyeceği fikri, dünya edebiyatı düşüncesinin çıkış noktası, temel hedefi olmuştur. Goethe'nin “Ulusal edebiyat artık anlamını yitirmiş bir terimdir; dünya edebiyatı çağı kapıdadır ve herkes onun yaklaşımını hızlandırmak için elinden geleni yapmalıdır." (Kirsch, 2019, s. 8) sözleri, küresel edebiyat çağına giden yolun ilk taşlarıdır. Bugünden bakıldığında Goethe'nin dileğinin onun arzusundan daha hızlı bir biçimde gerçekleştiği de ortadadır.

Dünya edebiyatı çağında, geride kalan neredeyse iki yüzyılın ardından, 21. yüzyılda, bütün dillerde ve kültürlerde yazılmış anıtsal kitaplara erişmek hiç bu kadar kolay olmamıştır. İster Gılgamış destanını, ister Genji’nin Hikâyesini, ister Tibet'in Ölüler Kitabı'nı, ister Savaş ve Barış'1 -hatta ister Goethe'nin kendi eserleriniokumak isteyin, hepsi 'mouse'unuzun bir tıkına bakar. Dahası yaşayan yazarlar da hiçbir zaman, dünyanın dört bir yanındaki çağdaşlarının eserlerine ilişkin bu denli ayrıntılı ve güncel bilgiye sahip olmamıştır. (...) Teknoloji, kültür ve ekonomi alanındaki bütün gelişmeler, bu birleşmenin giderek daha da artacağını gösteriyor. Bir uygarlık felaketi dışında, edebiyatın artık o dar, üstelik salt ulusal bakış açısına geri dönebileceğini düşünmek neredeyse imkânsız. (Kirsch, 2019, s. 8-9.)

Goethe'nin ortaya attığı dünya edebiyatı (Weltliteratur) terimi, hem edebî hem de kültürel perspektifte farkındalığa ve modernite eğilimine ışı tutmakla birlikte (Damrosch, 2016, s. 1) gelinen noktada küresel bir boyut kazanmıştır. Özellikle postmodernizm, postkolonyalizm, yapısökümcülük gibi modern sonrasının oyunsu, eklektik ve amorf atmosferinde epey bir kafa karışıklığına ve tartışmalara neden olmuştur. Öyle ki antikite ile modern arasındaki ilişki, kitle kültürü ile elit üretimlerin algılanışı, merkez edebiyatların çevre edebiyatlar üzerindeki tahakkümü bağlamındaki tartışmalar sürgit devam etmiştir (Demir 2019, s. 12). Bu sert polemiklere Türkiye'den katılan Cemil Meriç, “adı, 1827'de konmuş. Ama hâlâ aydınlık bir tarifi yok" (Meriç, 1998, s. 17) dediği dünya edebiyatı kavramını tartışırken önce "hangi dünya" ve "hangi edebiyat" kavramlarını sorgular. Ona göre dünya edebiyatı, daha çok Asya ve Avrupa odaklı tartışılmakta, sadece yazılı edebiyata sahip belirli ulusları kapsamaktadır. Dünyanın önemli bir bölümünü dışarıda bırakan bu eğilim, aynı zamanda Batı emperyalizminin kendi kültürel hegemonyasını diğer diller ve edebiyatlar üzerinde sürdürmesine hizmet etmektedir. Ancak eşitlik ilkesine dayalı edebî temaslar, ön yargılardan azade değerlendirmeler ve güçlü ulusal edebiyatlar üzerinden kurulan ilişkiler gerçek anlamda bir dünya edebiyatının kapıları açabilir. "Nitekim Goethe'nin de Alman edebiyatının diğer Avrupa edebiyatlarıyla at başı gidecek bir birikime ve güce sahip olduğunda yani kendini gerçekleştirdiği ve ispatladığ 1 anda sınırların ötesine uzanmasını istediğini dile getirir." (Meriç, 1998, s. 27) Adam Kirsch 
ise "Küresel Roman: 21. Yüzyılda Dünyayı Yazmak" adlı eserinde "Yerel olan, dünya çapında bir fenomenin parçası olarak görülebildiği oranda saygınlık ve anlam kazanır.” diyerek (2019, s. 11) küresel romanın ulusal roman için bir tehdit olmadığını aksine onun kendisini daha büyük bir platformda gösterebilmesine imkân verdiği için önemli kazanımlar sağladığını savunur. Adı küresel edebiyatçılar arasında çokça geçen Orhan Pamuk'a göre de "Dünya edebiyatı; yazarlar bir dünya edebiyatı olsun diye düşündükleri için değil, başka yazarlara ihtiyaç duydukları için oluşmuştur.” (Damrosch, 2009, s. 24). Pascale Casanova da büyük ya da merkezî sayılan edebiyatlarla periferide kalmış, görece küçük edebiyatlar arasındaki ilişkide periferilerden, üçüncü dünyadan gelen yazarların kimi noktalarda daha şanslı olduğunu söyler. Casanova için edebiyatın merkezine ulaşmak isteyen bu yazarlar, "Edebiyat dünyasının eşitsizlik üzerine kurulu yapısındaki özgül yasalara ve kuvvetlere göğüs germeyi uzun zaman önce öğrenmiştir, ayrıca yazar olarak ayakta kalmanın yolunun bu merkezlerde kabul görmekten geçtiğinin farkındadırlar. Yazar olarak kimliklerinin temelinde, bu farkındalık ve edebî düzene karşı isyan vardır.” (Casanova, 2010, s. 58). Özcesi, günümüzde küresel edebiyat kavramı etrafında sürdürülen tartışmalar ulusal edebiyat-küresel edebiyat, sömürgecilik-modernleşme, yerelleşme-küreselleşme, yozlaşma-gelişme, popülerleşme estetikleşme, içe kapanma-yayılma skalasında devam etmektedir.

Dünya edebiyatından küresel edebiyata geçiş noktasında ise 1960'larla başlayıp Doğu Bloku'nun çöküşüyle tamamlanan süreç, bir milat olarak kabul edilebilir. Bu dönemdeki toplumsal ve politik hareketler, teknolojinin ve iletişim imkânlarının çoğalmasıyla ulusal sınırların ötesine sıçramış, yaşamın her alanını olduğu gibi edebiyatı da başka bir aşamaya taşımıştır. Artık, birçok şey salt ulusal ve mahallî paradigmaların içerisinde tam olarak anlaşılamayacaktır. Kültürel ve edebî dönüşümlerin tetikleyicisi olarak bir toplumsal hareketin gerekliliği ilkesi (Eagleton, 2005, s. 143) gerçekleşmiştir ve cinin şişeden çıkması gibi küresel çağın kapısı ardına kadar aralanmıştır. Doğrularıyla yanlışlarıyla, getirdikleriyle götürdükleriyle bundan sonraki her ekonomik, politik, bilimsel, sanatsal, kültürel ya da güncel meselenin tartışılmasında küreselleşme nosyonu göz önünde bulundurulmak zorundadır. Tim Parks'ın ifadesiyle küreselleşme, aslında insanlık tarihi boyunca bireyler ve toplumlar arasında var olan etkileşiminin “çok daha güçlü araçlarla hızlanmasıdır.” (Parks, 2019, s. 186). Elbette, insanlığın tanımaya, iletişime, etkilemeye, etkilenmeye, keşfetmeye, egemenlik altına almaya dayalı bu kadim arzusu, kapitalizmin küreselleşmesiyle birlikte artık ivme kazanmıştır. Küreselleşmenin, yoğun biçimde etkilediği sanatların başında da kuşkusuz, edebiyat gelmektedir. Dile bağlı bir sanat olarak yüzyıllar boyunca ulusal kültürün inşasındaki, aktarımındaki ve temsilindeki ana unsurlarından biri olan edebiyat, bugün büyük oranda, ulusal olanı aşmanın ve küresel boyuta geçmenin aracına dönüşmüştür. Teknolojinin özellikle son yarım asırdaki gelişimi, dijitalleşme, çeviri imkânlarının ve yayımlanma tekniklerinin olağanüstü bir hızla ilerlemesi, edebiyatı sadece ulusal sınırların içerisinde konumlandıran paradigmayı sarsmıştır. Dünyanın hemen her ülkesindeki ya da dilindeki edebiyat üretimiyle çok kısa sürede buluşma imkânı yakalayan edebiyat dünyasının paydaşları arasında da doğal olarak etkileşim artmıştır. Bu durum, hem yazar hem de okur açısından küresel bir atmosfer oluşturduğu gibi metnin içeriğini, biçimini ve 
yayımlanma tekniklerini radikal bir dönüşüme uğratmıştır. Öte yandan uluslararası festivaller, ödüller, sanal ortam üzerinde dünyanın hemen her yerindeki edebiyatçıların, okurların ve eleştirmenlerin katılabileceği etkinlikler başka bir edebiyat piyasasını da üretmiştir. Şöyle ki "Küreselleşme, çağdaş sanatla kültürel kimliğini bütünleştirmiş ve sanatı piyasalaştırmış, bu piyasaya da tüm dönemlerin ve coğrafyaların sanatını katmıştır. Sanatçılar yerelliğin sınırlarını aşarak, ancak yerelliklerinden kaynaklanan eşsiz nitelikleriyle ve otantiklikleriyle sanat dünyasına dâhil olmakta, küresel sanat dolaşımına girmekte, dünya kültürlerini ve sanatını izleyebilmekte, ilham alıp ilham vermektedirler." (Erdoğan, 2015, s. 81).

Küresel edebiyatın 1960'larla başlayıp 90'lı yılların başında Sovyetler Birliği'nin dağılmasına uzanan süreçteki varlığı, Milenyum ile birlikte iyice kökleşir. Küresel kapitalist çağın epey parlattığı bir kavram olarak Milenyum, yani 2000'li yıllar sonrası, insanlığa sonsuz umut vadeden bir ütopya, yeni bir çağ diye pazarlanır. Oysa işler, kısa sürede tersine dönmüştür. Kronikleşen ekonomik, ekolojik, toplumsal sorunlar, salgın hastalıklar ve nükleer savaş riski gibi felaket senaryoları edebiyatta daha çok distopik anlatıların önünü açmıştır. Fakat elindeki güçlü propaganda imkânlarıyla küresel edebiyat söylemi, varlığını bir biçimde tahkim etmeyi başarmıştır. Öte yandan, iletişimin gelişmesi, ulaşılabilirliğin ve tüketimin dünya çapında yaygınlaşması, yazar ve okur profilini baştan yaratmış; yazarın hedefi, büyük okur kitlesine seslenmek olmuştur. Bir bakıma edebiyatçı, "Büyük edebî günahı işleyip kitleye teslim olduğunda onun etki alanına düşmüştür.” (Escarpit, 1968, s. 124). Okurun beğenisine uygun -ekonomide arz/talep- eserler üretilmeye başlamış hatta okurun da yazma sürecine dâhil olduğu bir anlayış edebiyatı çepeçevre sarmış, yeni yüzyılda okurun rolü ve etkinliği artmıştır.

\section{Küresel Edebiyat Eğilimi ve Milenyum Sonrası Nobel Edebiyat Ödülleri}

Küresel kapitalizmin egemen olduğu günümüz dünyasında her alanda olduğu gibi edebiyatta da önemi artan olgulardan biri de ödül meseledir. Özellikle uluslararası alanda verilen ödüller, sadece edebî anlamda belirli bir saygınlığı tescillemekle kalmamış aynı zamanda maddi anlamda önemli bir getirinin kaynağı olmuştur. Bu bağlamda edebiyat ödülleri etrafındaki tartışmalar da yoğunlaşmış, çoğu zaman ödüllerin edebiyat dışı saiklerle verildiği ileri sürülmüştür. Yine uluslararası kitap fuarları, ödüllerin verildiği ve ödüllerle birlikte çeviri anlaşmalarının yapıldığı, edebiyatçıların küresel bir düzlemde boy gösterdiği, uluslararası bir pazara dönüşmüştür:

Dünya edebiyatı uzamındaki en özgür ülkeler bile artık uluslararası ticaret yasalarının gücüne tâbi; bu yasalar üretim koşullarını dönüştürürken metinlerin biçimini de değiştiriyor. Çok uluslu yayın gruplarının ortaya çıkması ve edebîlik görüntüsü veren uluslararası çapta başarı kazanmış romanların çok geniş alanlara yayılması, ticari güçlerden bağımsız bir edebiyatın düşüncesini bile şüpheli hâle getiriyor. (Casanova, 2010, s. 189). 
Küresel ölçekte verilen Man Booker Uluslararası Ödülü, Pulitzer Ödülü, Hugo Ödülü, Goncourt Akademi Edebiyat Ödülü gibi ödüller olsa da dünyanın en prestijli edebiyat ödülü, Nobel Edebiyat Ödülü’dür. Nobel Edebiyat Ödülü, dünya edebiyatının genel geçer yasalarını belirlemekte, genel anlamda sanatçılar ve eserler için de evrensel bir tescil niteliği taşımaktadır. “Avrupa’nın 20. yüzyılın başında benimsediği bu ödülün itibarı yavaş yavaş bütün dünyada kabul görmüştür. Bugün bütün yazarlar onu evrenselliğin bir teminatı ve edebiyat dünyasında sahip olunabilecek en büyük onur olarak görmektedir." (Casanova, 2010, s. 164). “Öyle ki bazı ülkeler (Güney Kore, Portekiz, Çin vb.), bu ödülü elde etmek için yoğun çaba harcamakta ve kampanyalar düzenlemektedir.” (Casanova, 2010, s. 165). Çünkü Nobel Edebiyat Ödülü, sadece edebiyatçılar ya da yayıncılar için değil ülkeler ve diller açısından da tanınırlığın ve saygınlığın bir aracıdır. Öte yandan Nobel'in uluslararası politik, sosyal ve kültürel durumların gözetilerek Batı kapitalizminin liberal değerlerine uygun olan eserlere verildiği tezi de dünya ölçeğinde epey yandaş bulmuştur. Bu bağlamda kimi edebiyatçılar ödülü reddetmiş (Jean-Paul Sartre ve Boris Pasternak), kimi ülkeler ödülün kendilerini politik anlamda zora sokmak için verildiğini ileri sürerek Nobel Edebiyat Ödülü’nü şüpheyle karşılamışlardır. Yüz yılı aşkın süredir devam eden bu tartışmaların bundan sonra da süreceği aşikârdır.

\subsection{Nobel Akademisinin Yapısi ${ }^{1}$}

Alfred Nobel'in (1833-1896) vasiyetiyle Nobel Vakfı kurulmuştur. Bu kurumun amacı; fizik, kimya, fizyoloji, tıp, iktisadi bilimler, edebiyat ve barış alanlarına önemli katkılar sağlamış kişileri ödüllendirmektir. Nobel Vakfının kurumları ise şunlardır: Norveç Nobel Komitesi, Kraliyet Bilimleri Akademisi, Karolinska Enstitüsü, İsveç Akademisi.

Nobel Edebiyat Ödülü, İsveç Akademisi üyelerinin oluşturduğu komite tarafından Nobel Vakfının İç Tüzük'ünde yer alan kurallara göre verilir. Tüzük’te aday gösterme kuralları açıkça belirtilmiştir:

Tablo 1. Nobel Edebiyat Ödülü'nde Aday Gösterme Kurallar1 ${ }^{1}$

\begin{tabular}{|l|l|}
\hline \multicolumn{2}{|c|}{ Adaylık Kuralları } \\
\hline \multicolumn{2}{|c|}{ Nobel Edebiyat Ödülü'ne aday gösterme yetkisi olanlar: } \\
\hline 1. & $\begin{array}{l}\text { İsveç Akademisi üyeleri ve dünya çapında eşdeğer işlevlere sahip diğer akademiler, kurumlar ve } \\
\text { topluluklar. }\end{array}$ \\
\hline 2. & Üniversitelerde ve kolejlerde edebiyat ve dil dersleri profesörleri. \\
\hline 3. & Önceki Nobel Ödülü sahipleri. \\
\hline 4. & Ülkelerinin edebiyatını temsil eden ve edebiyatının seçme örneklerini üreten yazarların kurul başkanları. \\
\hline
\end{tabular}

1 Nobel Edebiyat Ödülü’ne ilişkin oluşturulan tabloda yer alan bilgiler, vakfin resmi internet sitesi olan https:// www.svenskaakademien.se. adresinden alınmıştır. (Erişim tarihi: 10.11.2020) 
Dünyanın dört bir yanından gizlilik içerisinde aday olarak gösterilenler, İsveç Akademisinin Nobel Komitesine iletilir. Eleme yoluyla üç liste (uzun/yarı uzun/kısa) oluşturulur. Kısa liste, akademi üyelerine sunulur. Akademi üyeleri, sunulan listedeki adayların edebî eserlerini inceler ve ödülün sahibini belirler. Eserlerin incelenmesine yönelik Tüzük’te edebiyat ile ilgili genel açıklamalar yapılmıştır. "Nobel'in vasiyetinde edebiyat alanındaki ödüller dördüncü sırada yer almaktadır. Nobel'e göre ödül, 'belirli ideal bir yönde en mükemmel yapıtı' sunmuş olana, Stockholm'deki Akademi tarafından verilmelidir. Nobel ödüllerinin resmî internet sitesinde yer alan tüzüğe göre vasiyette, Stockholm'deki Akademi ile İsveç Akademisi’ne gönderme yapılmıştır.” (Küçükislamoğlu, 2014, s. 18).

Tüzük’te eserin içerik, biçim ve üslup olarak nitelikli olması vurgulanmıştır. Ayrıca ayrıntılı ve somut bir değerlendirme kıstasından bahsedilmemiştir. Eserlerin, çevrilmesi zor bir dilde yazılmış olması durumunda izlenmesi gereken yol ise şöyle belirtilmiştir:

Aday olan bir eser, dikkate değer bir sorun veya önemli bir masraf olmaksızın çevrilemeyecek bir dilde yazılmışsa önerilen bu çalışmayı değerlendirebilmesi için ödül veren kuruluş, eserin içeriğini esas almalıdır. Ödül veren kuruluş, çevrilmesi zor bir dilde yazılmış eseri, dil ve üslup gibi kriterler bağlamında değerlendirme sorumluluğunu üstlenme yükümlülüğü altında olmayacaktır. (The Nobel Prize, 2020).

İsveç Akademisinden seçilen üyeler, komiteyi oluşturur (Nadiren dişarıdan üye kabul edilir). Bu komite, İsveç Akademisine gönderilen mektupları/metinleri inceler. Metinlerin çevrilmesinde dış alan uzmanları ve çevirmenler önemli rol oynar. Neticede Nobel Vakfının yapıs1; Nobel Edebiyat Ödülü'ne aday gösterilme kuralları, aday gösterilen eserlerin incelenme yöntemleri genel hatlarıyla bu bağlamda gerçekleşir. Öte yandan Nobel Edebiyat Ödülü'nü kazanan edebiyatçının belirlenmesinde edebiyat dışı birtakım unsurların da etkili olduğu söylenebilir. Aslında, edebiyat dışı kriterler zamanla daha belirgin hâle gelmiş; ödülün sağladığ 1 maddî ve manevî getirinin artması, uluslararası kamuoyundaki etkisinin güçlenmesi bu tür değerlendirmelerin de çoğalmasına neden olmuştur. Yine böylesi önemli bir ödülün verilmesinde diğer alanlardaki ödüllerde olduğu gibi dünyanın politik, kültürel ve güncel panoramasının göz önünde bulundurulması da kaçınılmazdır. Nitekim Nobel Edebiyat Ödülünde, ilk verildiği 1901 yılından beri dünyanın konjonktürüne özellikle de Nobel Vakfının temsil ettiği Batılı özgürlükçü, demokrat ve liberal değerlere çok fazla ters düşmeyen isimler tercih edilmiştir. Soğuk Savaş yıllarında, daha politik tercihlerin öne çıktığı aşikârdır, sonrasında ise aşırılıkları, milliyetçi anlayışları dengelemek amacıyla Alfred Nobel'in vasiyetindeki "barış idealine" uygun seçimler öne çıkmıştır. Bu durum, Nobel Edebiyat Ödülü’nün zihniyet olarak başından beri küresel edebiyat eğilimine uyduğunun da göstergesidir. Belki de Goethe'nin ortaya attığ 1 dünya edebiyatı fikri, yarım asrı aşkın bir süre sonra verilmeye başlanan Nobel Edebiyat Ödülü ile desteklenmiştir. 


\subsection{Milenyum Çağı’’nda Nobel Edebiyat Ödülü Alan Sanatçılar ve Ödülü Alma Gerekçeleri}

\begin{tabular}{|c|c|c|}
\hline $\begin{array}{c}\text { Ödülü̈n } \\
\text { Verildiği Yıl }\end{array}$ & $\begin{array}{l}\text { Ödülü Alan } \\
\text { Sanatçı }\end{array}$ & Ödülün Veriliş Nedeni \\
\hline 2000 & Gao Xingjian & $\begin{array}{l}\text { Çin romanı ve draması için yeni yollar açan evrensel geçerliliğe, acı" } \\
\text { "iç görülere ve dilbilimsel ustalığa sahip bir ortam geliştirdiği için }\end{array}$ \\
\hline 2001 & VS Naipaul & $\begin{array}{l}\text { Bizi, bastırılmış tarihlerin varlığını görmeye zorlayan eserlerinde" } \\
\text { "birleşik bir algısal anlatıya ve kusursuz incelemeye sahip olduğu için }\end{array}$ \\
\hline 2002 & Imre Kertész & $\begin{array}{l}\text { Tarihin barbarca keyfiliğine karşı bireyin kırılgan deneyimini” } \\
\text { "destekleyen eserleri için }\end{array}$ \\
\hline 2003 & JM Coetzee & "Dışarıdan birinin şaşırtııı katılımını ustaca tasvir ettiği için" \\
\hline 2004 & Elfriede Jelinek & $\begin{array}{l}\text { Olağanüstü dilbilimsel coşkuyla toplumsal klişelerin saçmalığını" } \\
\text { ve onların boyun eğdirme gücünü ortaya çıaran romanlardaki ve } \\
\text { "oyunlardaki müzikal ses akışı ve karşıt sesler için }\end{array}$ \\
\hline 2005 & Harold Pinter & $\begin{array}{l}\text { Oyunlarında, gündelik gevezeliklerin altında uçurumun üstünü açtığı" } \\
\text { ve bireyi, baskının kapalı odalarına girmeye, onunla yüzleşmeye } \\
\text { "zorladığ için }\end{array}$ \\
\hline 2006 & Orhan Pamuk & $\begin{array}{l}\text { Memleketinin melankolik ruhunu ararken, kültürlerin çatışması ve iç" } \\
\text { "içe geçmesi için yeni semboller keşfettiği için }\end{array}$ \\
\hline 2007 & Doris Lessing & $\begin{array}{l}\text { Şüphecilik, ateş ve vizyoner güçle bölünmüş bir medeniyeti” } \\
\text { incelemeye tabi tutan kadın deneyiminin destansı anlatısını } \\
\text { "ggerçekleştirdiği için }\end{array}$ \\
\hline 2008 & $\begin{array}{l}\text { Jean-Marie Gustave Le } \\
\text { Clézio }\end{array}$ & $\begin{array}{l}\text { Yeni çıkışların, şiirsel maceranın ve şehvetli coşkunluğun yazarı ve" } \\
\text { "medeniyetlerin derinliğindeki insanlığın kâşsifi olduğu için }\end{array}$ \\
\hline 2009 & Herta Müller & $\begin{array}{l}\text { Şiirsel yoğunluğu ve nesir açıklığı ile mülksüzleri, kaybedenleri ve" } \\
\text { "tutunamayanları ustaca betimlediği için }\end{array}$ \\
\hline 2010 & Mario Vargas Llosa & $\begin{array}{l}\text { İktidarların tahakkümcü anlayışına karşı bireyin direnişine, isyanına" } \\
\text { "ve yenilgisine dair keskin gözlemlere dayalı eserleri için }\end{array}$ \\
\hline 2011 & Tomas Tranströmer & $\begin{array}{l}\text { Yoğunlaştırılmış, yarı saydam görüntüleri aracıllı̆̆ıla bize" } \\
\text { "gerçekliğe farklı ulaşım yolları gösterdiği için }\end{array}$ \\
\hline 2012 & Mo Yan & $\begin{array}{l}\text { Halüsinasyonla gerçekçiliği, halk masallarıla tarihi, gelenekselle" } \\
\text { "çağdaş olanı birleştirdiği için }\end{array}$ \\
\hline 2013 & Alice Munro & “Çağdaş kısa öykünün ustası olduğu için” \\
\hline 2014 & Patrick Modiano & $\begin{array}{l}\text { İnsanın en kavranamaz gibi görünen kaderlerini uyandırdığı ve" } \\
\text { "işgalin bireyin belleğindeki izdüşümlerini ifşa eden hafıza sanatı için }\end{array}$ \\
\hline 2015 & Svetlana Aleksievich & "Çağımızın acılarını cesurca betimleyen çoksesli yazıları için" \\
\hline 2016 & Bob Dylan & $\begin{array}{l}\text { Büyük Amerikan şarkı geleneği içinde yeni şiirsel ifadeler yarattığı" } \\
\text { "için }\end{array}$ \\
\hline 2017 & Kazuo Ishiguro & $\begin{array}{l}\text { Büyük duygusal güce sahip romanlarıyla, gerçeklikle hayallerimiz" } \\
\text { "arasındaki uçurumu ortaya çıkardığı için }\end{array}$ \\
\hline 2018 & Olga Tokarczuk & $\begin{array}{l}\text { Ansiklopedik tutkuyla yazdığı eserlerinde, bir yaşam biçimi olarak" } \\
\text { "sınırların aşılmasını temsil eden hayal gücüne sahip olduğu için }\end{array}$ \\
\hline 2019 & Peter Handke & $\begin{array}{l}\text { Dilsel ustalıkla insan deneyiminin çevresini ve özgünlüğünü" } \\
\text { "keşfeden etkili çalışmaları için }\end{array}$ \\
\hline 2020 & Louise Glück & $\begin{array}{l}\text { Sade güzelliğe sahip eserlerinde, bireysel varoluşu evrensel kılan" } \\
\text { "kusursuz şiirsel sesi için }\end{array}$ \\
\hline
\end{tabular}


Milenyum sonrası Nobel Edebiyat Ödülü’nün veriliş gerekçelerine dikkatli bakıldığı zaman, ödülü kazananların büyük oranda küresel edebiyat eğilimine uyan ya da en azından edebiyatın küresel paradigmasıyla çok fazla çatışmayan isimler olduğu görülebilir. Zaten bu isimlerin pek çoğu Nobel almadan önce edebiyatın uluslararası dolaşımına dâhil olan edebiyatçılardır. Örneğin Gao Xingjian, Çin romanı ve dramı için yeni yollar açıp evrensel gerçekliğe vurgu yapan eserler üretmiştir. Aynı şey Louise Glück'ün bireysel varoluşu evrensel kılan kusursuz şiirsel sesi için de geçerlidir. Naipaul, bastırılmış toplumsal acıları işleyen eserlerinde bir kin değil empati üretmeyi esas alan bir bakış açısı geliştirmiştir. Imre Kertész, benzer biçimde tarihin barbarca keyfiliğgine karşı bireyin kırılgan deneyimini öne çıkarmıştır. JM Coetzee, ötekinin/ötekileştirilen insanların varlığını eserlerinde ustaca göstermiştir. Elfriede Jelinek ise ötekinin kendini ifade etmesine imkân sağlayan bir anlatı ortamı inşa etmiştir. Harold Pinter, küresel roman teorisinin merkezinde yer alan liberal, demokrat ve özgürlükçü bireyi öne çıkararak bu bireyi, tarihî ve politik gerilimlerin üzerini örttüğü alanlarla yüzleşmeye zorlamıştır. Olga Tokarczuk, bu bireye sınırlarını aşması için hayal gücü vermiş, çevre ve insan ilişkisinin mistik boyutunu ele almıştır. Peter Handke de bireyin çevresini ve özgünlügüünü keşfetmesine yardımcı olmuştur.

Küresel edebiyatın önemli yazarları arasında gösterilen Orhan Pamuk, memleketinin melankolik ruhunu ararken, kültürlerin çatışması ve iç içe geçmesi için yeni semboller keşfetmiştir ki bu semboller de küresel edebiyat eğiliminin sentezci, uzlaşmacı ve çoğulcu ruhuyla örtüşür. Tıpkı Orhan Pamuk gibi Doris Lessing, Jean Marie Gustave Le Clézio, Mo Yan ve Kazuo Ishiguro da medeniyetler arası iletişim, ortaklık ve hoşgörüye vurgu yapan edebî eserler üretmişlerdir. Nitekim Doris Lessing, medeniyetler çatışmasını aşmak için kadın duyarlılığından beslenen destansı anlatılar kotarmış, Jean Marie Gustave Le Clézio ise bu çatışmanın derinlerinde yer alan insanlığın aslında ortak bir mirasın temsilcisi olduğuna işaret etmiştir. Kazuo Ishiguro, gerçeklikle hayallerimiz arasındaki uçurumu ortaya çıkarmış, Mo Yan ise geleneksel olanla moderni birleştirerek medeniyetler arası ilişkinin tarihî köklerine yönelmiştir. Elbette, Nobel alanlar arasında toplumsal konulara, adalete, eşitliğe daha fazla vurgu yapan edebiyatçılar vardır fakat toplumsal eleştiri dozu da büyük oranda küresel edebiyat eğiliminin bakış açısıyla örtüşür. Örneğin Herta Müller, şiirsel yoğunluğu ve nesir açıklığı ile mülksüzleri, kaybedenleri ve tutunamayanları ustaca betimlediği için ödüle layık görülmüştür. Benzer biçimde Mario Vargas Llosa, iktidarların tahakkümcü anlayışına karşı bireyin direnişine, isyanına ve yenilgisine dair keskin gözlemlere dayalı eserlerinden dolayı ödülü kazanmıştır. Patrick Modiano ise insanın en kavranamaz gibi görünen kaderlerini uyandırdığı ve işgalin bireyin belleğindeki izdüşümlerini ifşa edebildiği için Nobel'i almıştır.

Milenyum sonrası Nobel Edebiyat Ödülü'nü kazanan edebiyatçılar, sadece içeriklerinin veya bakış açılarının küresel edebiyat eğilimiyle örtüşmesi nedeniyle değil aynı zamanda üslup ve teknikleriyle de zamanın ruhuna denk düşen eserler verdikleri için ödüle sahip olmuşlardır. Örneğin Tomas Tranströmer'in “yoğunlaştırılmış, yarı saydam görüntüler aracılığıyla gerçekliğe dair farklı ulaşım yolları göstermesi”, küresel edebiyatın çoğulcu, karnavalesk yapısına uygundur. Alice Munro'nun “çağdaş anlamda kısa öykünün ustası” olmasından ötürü Nobel'i alması, 
görsellik çağının egemen olduğu günümüz dünyasında, küresel edebiyatın öne çıkardığı bir tür olan "küçürek öykünün” ödüllendirilmesi olarak değerlendirilebilir. Öte yandan Svetlana Aleksievich'in “çağımızın acılarını cesurca betimleyen çok sesli yazıları”, Bob Dylan’ın şiiri müziğe yaklaştıran disiplinler arası çalışmaları hep küresel edebiyat anlayışının temel eğilimlerinden postmodernizmi akla getirir. Yine edebiyatçının uluslararası edebiyat ve sanat dünyasındaki görünürlüğü, eserlerinin Batı dillerinde yazılmış olması (İngilizce, Fransızca ve Almanca) ya da kolay çevrilebilir özellikler taşıması da Nobel Edebiyat Ödüllerinin verilmesinde etkili olmuştur. Ek olarak edebiyatçının hem ülkesindeki hem de dünyadaki sorunlara eleştirel bir gözle bakması, Batılı değerlerle uyumlu, demokrat, liberal ve özgürlükçü bir aydın vasfı taşıması da ödüllerin dağılımında dikkat çeken bir başka husustur.

\subsection{Milenyum Sonrası Nobel Edebiyat Ödüllerinin Çeşitli Değişkenlere Göre Dağılımı}

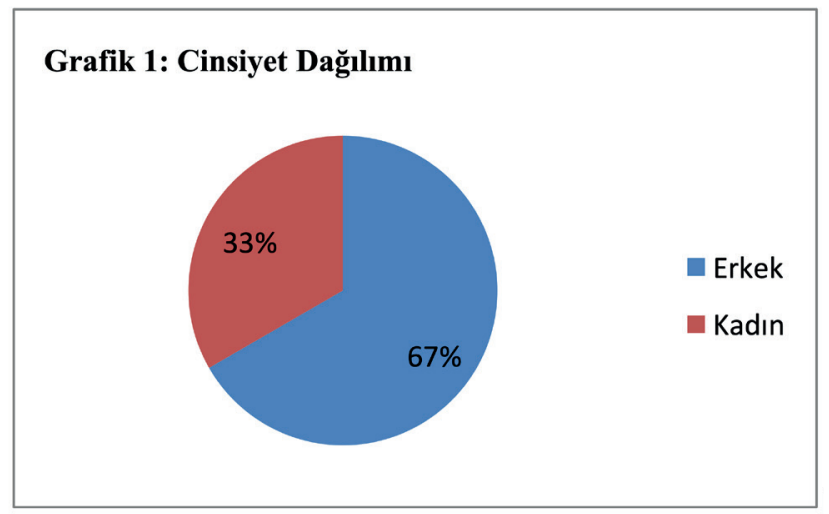

Grafik 1'de belirtildiği üzere 2000-2020 yılları arasında Nobel Edebiyat Ödülü alan kadın edebiyatçıların sayısının daha önceki dönemlere oranla belirgin bir artış göstermesi küresel edebiyat eğilimiyle örtüşmektedir. Nitekim 2000 yılına kadar 95 Nobel Edebiyat Ödülü’nün sadece 9'unu kadınlar kazanmışken son 20 yılda 7 kadın edebiyatçı Nobel Edebiyat Ödülü'ne layık görülmüştür. Milenyum öncesi dönemde \%10 olan Nobelli kadın edebiyatçı oranı, Milenyum sonrasında \%33 olarak gerçekleşmiştir. Üç katı aşan bir oranda artan kadın yazar sayısı neredeyse erkeklere yetişmiştir. Nobel Edebiyat Ödülü’nü kazanan kadın edebiyatçıların sayısındaki artışın başlıca sebepleri arasında; hem kadınların yaşamın her alanındaki varlıklarının güçlenmesi hem de küresel edebiyat anlayışının temel izleklerinden birinin kadın hakları ve feminizm gibi evrensel bir tema olması gösterilebilir. Kadınların küresel ölçekte verdikleri mücadele, Milenyum sonrasında daha da görünürlük kazanmış, oluşturdukları entelektüel güç ve edebî kamuoyu da Nobel'in kadın yazarlara verilmesinde etkili olmuştur. 


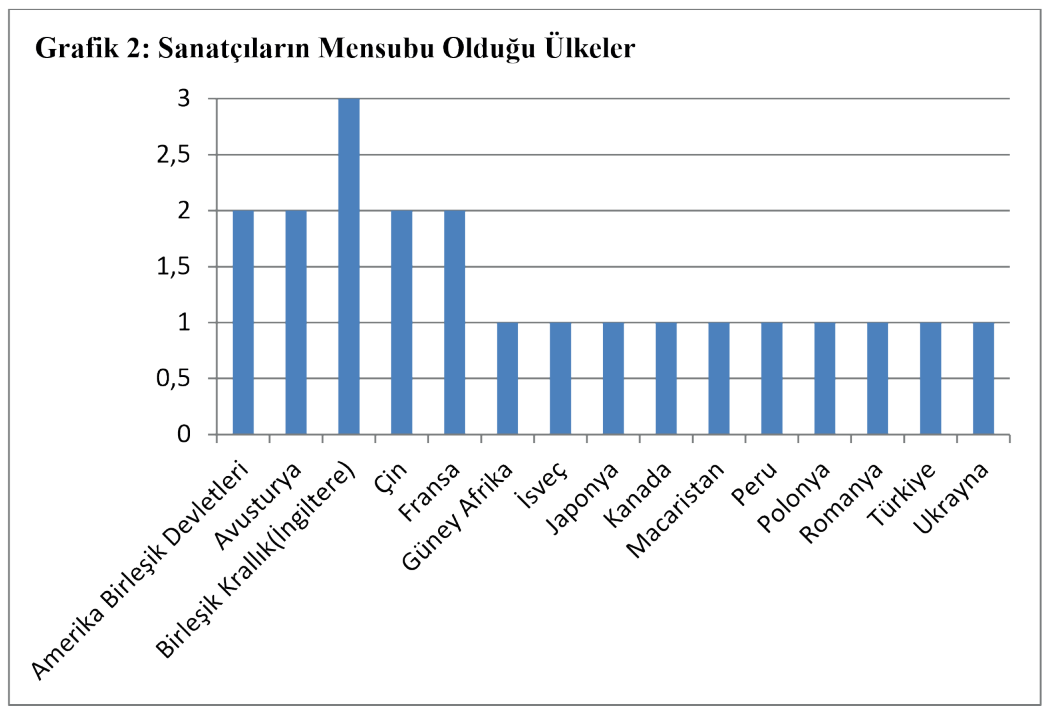

Grafik 2'de, son yirmi bir yılda Nobel Edebiyat Ödülü'nü alan sanatçıların mensup olduğu ülkeler sıralanmıştır. İngiltere’ye (Birleşik Krallık) üç; Amerika Birleşik Devletleri, Avusturya, Çin ve Fransa’ya iki defa ödül gitmiştir. Güney Afrika, İsveç, Japonya, Kanada, Macaristan, Peru, Polonya, Romanya, Türkiye, Ukrayna bir kez ödül almıştır. Nobel listesinin bütününe bakıldığı zaman Batı merkezli bir algının 1980'lerden başlayarak daha küresel bir boyuta evirildiği, Milenyum sonrasında ise bu eğilimin daha hızlandığını söyleyebiliriz. Nitekim 114 Nobel Edebiyat Ödülü içerisinde Batı dünyası olarak nitelenen Avrupa ülkeleri, ABD, Kanada ve Avustralya'ya giden Nobel Edebiyat Ödülü sayısının 99 olması ve 1980’e gelene kadar Batı dünyası dışındaki edebiyatçıların sadece 5 tane Nobel kazanması ödüllerin dağılımındaki Batı medeniyeti merkezli yaklaşımın 1980’lere kadar katı bir biçimde devam ettiğini gösterir. "Dünyanın önemli bir bölümünü dışarıda bırakan bu eğilim, aynı zamanda Batı emperyalizminin kendi kültürel hegemonyasını diğer diller ve edebiyatlar üstünde sürdürdüğünün de göstergesidir." (Demir ve Arvas, 2020, s. 170).

1980 sonrasında ise Soğuk Savaş Dönemi'nin sona ermesi, küresel kapitalist çağın güçlenmesi ve dijitalleşmenin ortaya çıkardığı basım, yayım, çeviri ve dolaşım imkânları sayesinde Batı ülkeleri dışındaki Nobel Edebiyat Ödülleri sayısı 14'e ulaşmıştır. Tüm bu veriler, Nobel Edebiyat Ödülü’nün kriterleriyle küresel edebiyat eğiliminin paftaları arasındaki çakışmayı göstermektedir. Bu diyalektik ilişkinin daha derin ve sıkı bir boyutu da özellikle Milenyum sonrasındaki Nobelli edebiyatçıların çok kültürlü, çok dilli kimlikleridir. Örneğin Gao Xingjian Çinli olmasına rağmen Nobel kayıtlarına Fransız edebiyatçısı; Ishiguro Japon, Naipul da Trinidadlı olmalarına rağmen İngiliz edebiyatçıları diye geçmişlerdir. Yine Clezio’nun ödülünün Fransa-Mauritus, Mario Vargas Llosa'nınki ise Peru-İspanya diye verilmesi, bu yazarların iki farklı ülkenin edebiyatı içerisinde kabul edildiklerini gösterir. Benzer şeyler İran'da doğup İngiltere'de yetişen Doris Lessing, Güney Afrikalı olmasına Avustralya'da 
yaşayan Coetzee ile Nobel'i kazanmadan çok önce dünyanın küresel edebiyat atmosferine dâhil olan Orhan Pamuk için de söylenebilir. Demek ki Goethe'nin önceleri Avrupa merkezli diye tasarladığı dünya edebiyatının, 1980’lerden sonra küresel edebiyata dönüşüp cihanşümul bir hüviyet kazanması süreci ile Nobel Edebiyat Ödülü’nün tarihi serencamı arasında güçlü bir korelasyon vardir.

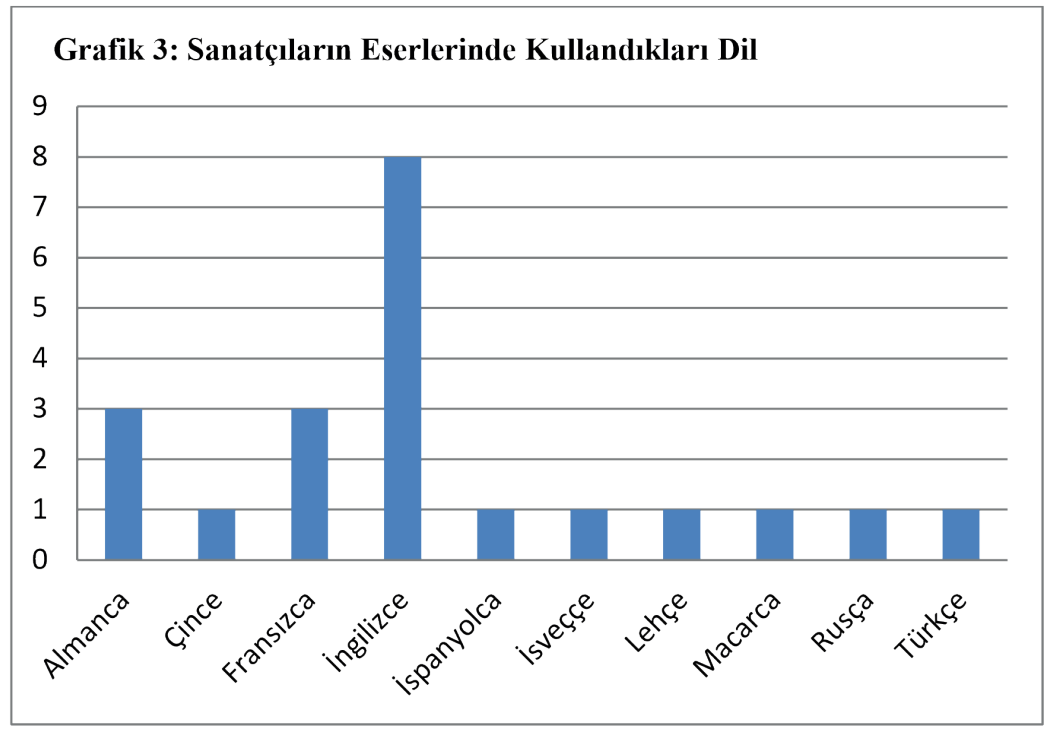

Grafik 3'te, Nobel Edebiyat Ödülü’nü kazanan edebiyatçıların eserlerini yazdıkları diller sıralanmıştır. 2000-2020 yılları arasında ödül alan edebiyatçıların 8'i İngilizce, 3'ü Almanca, 3'ü de Fransızca yazmıştır. Diğer edebiyatçıların kullandı̆̆ı diller ise (bir defa) Çince, İspanyolca, İsveççe, Lehçe, Macarca, Rusça ve Türkçedir. Görüldüğü gibi listeyi İngilizce domine etmektedir. Küresel edebiyat eğilimine yönelik eleştirilerden biri de ulusal dilleri ve kültürleri ikinci plana iterek İngilizcenin hâkimiyetini öne çıkarması ve bir anlamda bir kültür emperyalizmine sebep olmasıdır. Ulusal edebiyatlar üzerindeki sömürgeciliğin küresel kapitalist çağda biçim değiştirerek devam ettiğini ileri süren kimi ulusalcı ya da solcu çevrelerin Nobel Edebiyat Ödülü’ne dair yukarıdaki veriyi sıkça dillendirdiklerini belirtmek gerekir. Ama öte yandan küresel edebiyat anlayışı, ulusal dilde de yazılsa kültürel kökenlerinin ötesinde dolaşıma giren tüm edebiyat eserlerini kapsayan bir sahadır ve ister istemez ya çeviri etkinliğiyle ya da bizatihi edebiyatçının küresel dilde (İngilizce) yazmasıyla işlerlik kazanır. Çünkü "En geniş anlamıyla yurdunun ötesine ulaşmış her eser dünya edebiyatına dâhil edilebilir, öte yandan bir eser ancak asıl kültürünün ötesinde bir edebiyat sisteminde bilfiil mevcutsa dünya edebiyatında faal bir yaşamı olabilir.” (Damrosch, 2003, s. 32). Bu bağlamda kendilerini edebiyatın uluslararası sistemine akredite etmek isteyen yazarların İngilizce başta olmak üzere Fransızca ve Almanca gibi Batı medeniyetinin merkezî dillerine yöneldiklerini ve elbette, Nobel Edebiyat Ödülü’nün de bu eğilimi desteklediği söylenebilir. 


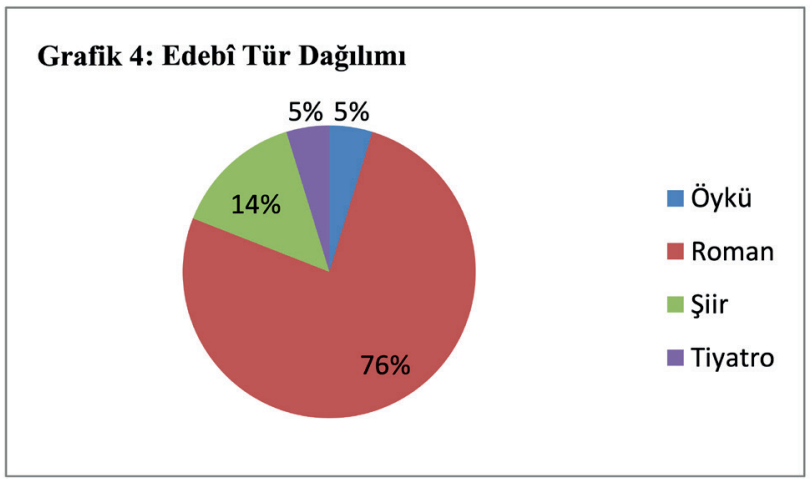

Grafik 4'te, Nobel Edebiyat Ödülü alan edebiyatçıların yazdıkları eserlerin tür olarak dağılımı verilmiştir. Sanatçılardan 16'sı (\%76) roman, 3’ü (\%14) şiir, 1'i (\%5) öykü, 1'i (\%5) tiyatro türünde yazdıklarıyla öne çıkmıştır. Nobel Edebiyat Ödülü ile küresel edebiyat eğiliminin kesiştiği önemli noktalardan biri de tür meselesidir. Nitekim romanla kıyaslanmayacak kadar tarihî bir arka plana sahip olan şiir, listede romanın çok gerisinde kalmıştır. Hatta Nobel Edebiyat Ödülü'nün genellikle romancılara verildiği bu nedenle de bir roman ödülü olduğu ileri sürülebilir. Öte yandan şiirin ulusal dile bağlı, başka dile çevrilmesi estetik değerinden büyük kayıplara yol açacak ve elbette edebiyat endüstrisine uygun olmayan doğasının aksine roman, tam da küresel edebiyat eğiliminin amaçlarına uygun bir tür olarak Nobel Edebiyat Ödülü'ne damgasını vurmuştur. Başka bir ifadeyle dünya edebiyatı fikrinin öncüsü Goethe'nin “insanlığın evrensel mülkü” olarak nitelediği şiir, süreç içerisinde tahtını romana bırakmıştır. Şiirin küresel edebiyat açısından taşıdığı handikapların bir diğeri de duyguya hitap etmesi ve yoğun imge ve mecazlar içermesidir. 21. yüzyılın doğası ise enformasyon/bilişimdir. Aklın/ düşünmenin ön planda olması, bilginin göreceliği, değişkenlik romanı başat tür konumuna getirmiştir. Ayrıca roman, biçim olarak oldukça uzun ve kapsamlı bir yapıya sahiptir; bu nedenle dünya edebiyatını besleyen bir kaynaktır ve tür olarak en fazla tartışılan/yorumlanabilen/ alımlanabilen alandır. Roman (çağa uygun olarak), modernizmin ve postmodernizmin etkisiyle biçimsel olarak başkalaşım geçirmiş, küresel nitelik kazanmıştır. Özellikle postmodernizmde kullanılan "metinlerarası, parodi, pastiş, kolaj, anakronizm, alışılmamış bağdaştırmalar, oksimoron" gibi teknikler; romanın çoklu bir anlatıya, hatta anlatılar külliyatına dönüşmesini sağlamıştır. Bu nedenle her okur, kendine göre eseri yeniden kurgulama ve alımlama imkânı yakalamıştır. Yine Milenyum Çağı romanı; ulusal kimliklerin aşıldığı, yerel aidiyetlerin ikinci plana itildiği, dünya ölçeğinde düşünmeye dayanan anlatılardır. Küresel roman, muhtevasını evrensel konular etrafında kurgular. Kurguda çoğulculuk hâkimdir, konuların dünyayı temsil etme gücü vardır. Bu bağlamda; ekoloji, salgın, göç, sürgün, diaspora, kültür çatışması, aidiyetsizlik, kimlik krizi, yabancılaşma, distopya gibi konular melez ve hibrit roman kişileri ve ülkelerin hatta kıtaların ötesine geçen uzamlar içerisinde sunulur. 


\subsection{Nobel Ödülü Alan Sanatçıların Türkçeye Çevrilen Eserlerinin Konu Dağılımı}

Bu bölümde, Nobel Edebiyat Ödülü alan edebiyatçıların Türkçeye çevrilmiş eserlerinde öne çıkan temalar listelenmiştir.

\begin{tabular}{|c|c|c|c|}
\hline Yazar/Sanatçı Adı & Eserin Adı & Konusu & Türü \\
\hline \multirow{2}{*}{ Gao Xingjian } & Ruh Dă̆l & Aşk, Köken, İç Yolculuk & \multirow{2}{*}{ Roman } \\
\hline & Yalnız Bir Adamın Kitabı & Yalnızlık, Devrim, Baskı & \\
\hline \multirow{2}{*}{ V.S. Naipaul } & Mistik Masör & Aşk, Sömürgecilik, Politika & \multirow{2}{*}{ Roman } \\
\hline & Gelişin Bilmecesi & Sömürgecilik, İç Yolculuk & \\
\hline \multirow{2}{*}{ Imre Kertész } & Doğmayacak Çocuk Iç̧in Dua & Savaş, Soykırım & \multirow{2}{*}{ Roman } \\
\hline & Tasfiye & Soykırım, Ölüm & \\
\hline \multirow{2}{*}{ JM Coetzee } & Utanç & Irk Ayrımı, Ötekileştirme & \multirow{2}{*}{ Roman } \\
\hline & Barbarlart Beklerken & Soykırım, Aşk, Zorbalık & \\
\hline Elfriede Jelinek & Piyanist & Aşk, Psikolojik Sorunlar & Roman \\
\hline \multirow{2}{*}{ Harold Pinter } & Aldatma & Aşk & \multirow{2}{*}{ Oyun } \\
\hline & Kutlama & Sınıflaşma(Alt-Üst Tabaka) & \\
\hline \multirow{2}{*}{ Orhan Pamuk } & Kara Kitap & Aşk, Gizem, Tarih & \multirow{2}{*}{ Roman } \\
\hline & Kar & Siyasî Çatışma, Ötekileștirme & \\
\hline \multirow{2}{*}{ Doris Lessing } & Şikeste & Dünya Tarihi, Savaş, Kıtlık, Yok Oluş & \multirow{2}{*}{ Roman } \\
\hline & İyi Terörist & Çatışma, Eylem, İdeoloji & \\
\hline \multirow{2}{*}{$\begin{array}{c}\text { Jean Marie Gustave } \\
\text { Le Clézio }\end{array}$} & Göçmen Yıldız & Soykırım, Savaş, Aşk & \multirow{2}{*}{ Roman } \\
\hline & Açlı̆̆ın Şarkısı & Sömürgecilik, Savaş & \\
\hline \multirow[b]{2}{*}{ Herta Müller } & Yürekteki Hayvan & Korku, Baskı, Arkadaşlık & \multirow[b]{2}{*}{ Roman } \\
\hline & $\begin{array}{l}\text { Keşke Bugün Kendimle } \\
\text { Karşılaşmasaydım }\end{array}$ & Ötekileştirme, İnsan İlişkileri, Baskı & \\
\hline \multirow[b]{2}{*}{ Mario Vargas Llosa } & Cennet Başka Yerde & Cinsellik, Feminizm & \multirow[b]{2}{*}{ Roman } \\
\hline & $\begin{array}{c}\text { Palomino Molero'yu Kim } \\
\text { Öldürdü? }\end{array}$ & Cinayet, Kötülük & \\
\hline \multirow{2}{*}{ Tomas Tranströmer } & Ateş Karalamaları & Doğa ve Endüstri Uzlaşma & \multirow{2}{*}{ Şiir } \\
\hline & $\dot{I} z m i r$ Saat $\ddot{U} c ̧$ & Duygular(Sevinç Hüzün) & \\
\hline \multirow{2}{*}{ Mo Yan } & Kızıl Darı Tarlalart & Savaş, Direniş, Devrim & \multirow{2}{*}{ Roman } \\
\hline & Yaşam ve Ölüm Yorgunu & Tarihsel Değişim, Farklı Kimlikler & \\
\hline \multirow[t]{2}{*}{ Alice Munro } & Sevgili Hayat & Aşk, Yalnızlık & \multirow{2}{*}{ Öykü } \\
\hline & Nefret, Arkadaşlık, Flört, Aşk, Evlilik & İnsan İlişkileri & \\
\hline \multirow[b]{2}{*}{ Patrick Modiano } & Mahallede Kaybolma Diye & İç Yolculuk, Travma & \\
\hline & En Uzağından Unutuşun & $\begin{array}{c}\text { Dostluk, Aşk, Dişa Vurulmayan } \\
\text { Duygular } \\
\end{array}$ & Roman \\
\hline Suetlang Aleksievich & Çernobil Duası Geleceğin Tarihi & Nükleer Felaket & \\
\hline Svetlana Aleksievich & Kadın Yok Savaşın Yüzünde & II. Dünya Savaşı ve Etkileri & Roman \\
\hline Bob Dylan & & Özgün Şiirsel İfadeler & Şark1/Şiir \\
\hline Kazun Ishiguro & Günden Kalanlar & Umut, Hayal Kırıklı̆̆g, Özlem & \\
\hline Kazuo Ishiguro & Beni Asla Bırakma & Diş Dünyadan Kopuş & Roman \\
\hline & Kadim Zamanlar ve Diğer Vakitler & İnsanlığın Değişimi, Dünya Tarihi, Mit & \\
\hline Olga Tokarczuk & $\begin{array}{c}\text { Sür Pulluğunu Ölülerin Kemikleri } \\
\text { Üzerinde }\end{array}$ & Doğa ve İnsan Gizem & Roman \\
\hline Deter Handke & Solak Kadın & Yalnızlık, Aile & Roman \\
\hline Peter Handke & Çocuğun Öyküsü & Aile & Anlatı \\
\hline Louise Glück & Seçme Şiirler & $\begin{array}{l}\text { Ölüm, Kaybetme, Devimin, } \\
\text { Yenileşme, Kadın Dünyası }\end{array}$ & Şiir \\
\hline
\end{tabular}


Bu tablodan yola çıkarak Nobelli yazarların işledikleri temaların küresel edebiyatın izlekleriyle benzerlik gösterdiği tespit edilmiştir. Ele alınan konu özetlenecek olursa denilebilir ki dünya edebiyatı, edebiyatın evrenselliğini; insan kültürünü meydana getiren yapı taşları olan arketipsel birlik ile mümkün kılmaya çalışmıştır. İnsanlığın ortak hafızasına yönelerek benzer konularda (savaş, dünya tarihi, aşk, cinsellik, aile, ölüm, doğa-insan etkileşimi vs.) edebî ürünler meydana getirmek, dünya edebiyatı düşüncesinin nirengi noktası olmuştur. Batı dünyası dışındaki kültürlerin katılımıyla da bu harita epey genişlemiştir. "Casanova'ya göre, Batılı olmayan edebiyat kültürleri, dünya edebiyat uzamında fiilen ilk kez yirminci yüzyılın ortasında, sömürgelerin çözülüşü döneminde belirmişlerdir.” (Mufti, 2009, s. 193). 20. yüzyılda yaşanan savaşlar, savaşların yarattığı maddî ve manevî yıkımlar, doğa-insan etkileşimi, soykırım, devrimler, çatışmalar, Nobelli yazarların katkılarıyla da dünya edebiyatından küresel edebiyata uzanan anlayışın başlıca temaları olmuştur.

\section{Sonuç}

Nobel Edebiyat Ödülü ile küresel edebiyat nosyonu arasında, kökleri ödülün ilk verildiği dönemlere kadar götürülebilecek sıkı bir ilişki vardır. Bir bakıma Nobel Edebiyat Ödülü’nün tarihi aynı zamanda edebiyatın küreselleşme tarihidir. Çünkü İsveç Akademisinin temsil ettiği Batıl1, liberal ve demokrat değerler küresel edebiyatın da benimsediği başlıca ilkelerdir. Yine özellikle Milenyum sonrası dönemde, Nobel Edebiyat Ödülü'nü kazanan edebiyatçıların kahir ekseriyeti, küresel edebiyat eğilimine yakın duran kimselerdir. Zira tüm insanlığı ilgilendiren konuları evrensel bir bakış açısıyla ideolojik bağnazlıktan uzak, daha 1lımlı, daha sentezci, daha uzlaşmacı bir üslupla kotarmışlardır. Dil ve anlatım konusunda da evrensel bir okur kitlesini hedefleyen, çok kimlikli/çok dilli edebiyatçılar, çoğu zaman kendi ana dili yerine İngilizce ya da Fransızca yazmayı tercih etmiştir. Kendi ana dilinde yazanlar ise çevirisi kolay sayılabilecek, yerel ve ulusal unsurları küresel okurun anlayabileceği bir üslupla sunan eserler üretmişlerdir. Ulusal dilin şiirselliğini, metaforik ve sanatlı kullanımını pek tercih etmeyen bu edebiyatçıların yaşamlarını da uluslararası bir düzlemde sürdürdüğünü eklemek gerekir. Âdeta, bir dünya vatandaşı gibi yaşayan bu edebiyatçıların yeni bir edebiyat çağının öncüleri olduğu da aşikârdır. 2000'den sonra Nobel Edebiyat Ödülü’nü kazanan kadın edebiyatçı sayısının önceki dönemle kıyaslanmayacak kadar artması, edebî türler arasında da romanın Milenyum sonrasındaki listeyi domine etmesi küresel edebiyatın ruhuyla örtüşür. Bu bağlamda Milenyum sonrası Nobel Edebiyat Ödülü ile dile bağlı bir sanat olarak yüzyıllar boyunca ulusal kültürün merkezinde yer alan edebiyatın, küresel boyuta evirildiği söylenebilir. Elbette teknolojinin, ulaşımın, demografik hareketlerin son yarım asırdaki gelişimi, dijitalleşme, çeviri imkânlarının ve yayımlanma tekniklerinin ivme kazanması, edebiyatı sadece ulusal sınırların içerisinde konumlandıran paradigmayı sarsmıştır. Dünyanın hemen her ülkesindeki ya da dilindeki edebiyat üretimiyle çok kısa sürede buluşma imkânı yakalayan edebiyat dünyasının paydaşları arasında da doğal olarak etkileşim artmıştır. Bu durum, hem yazar hem de okur açısından küresel bir ortam oluşturduğu gibi metnin içeriğini, biçimini ve yayımlanma tekniklerini radikal bir dönüşüme uğratmıştır. Goethe'nin 19. yüzyılın ilk yarısında ortaya attığı "Dünya Edebiyatı" kavramı, onun öngörülerinin de ötesine geçerek özellikle Milenyum ile birlikte 
küresel edebiyata dönüşmüş; kültür ve sanat dünyasının temel nosyonu olmuştur. Yaşamın her alanında olduğu gibi edebiyatta da küreselleşme eğilimine karşı çıkan milliyetçi ve Marksist çevrelerin emperyalizmin edebiyat kurumlarından biri olarak değerlendirdiği Nobel Edebiyat Ödülü’nü tıpkı Oscar Ödülleri gibi şüpheyle karşılaması, küresel kapitalizmin devamına hizmet eden araç biçiminde nitelemesi de bu bağlamda düşünülmelidir. Son tahlilde, Nobel Edebiyat Ödülü ile küresel edebiyat anlayışı arasındaki diyalektik ilişkiyi anlamak, sadece yaşadığımız çağın değil; geleceğin edebiyat ve kültür atmosferini anlamlandırmak, tahlil etmek, sorunlarına çözüm önerileri getirebilmek için elzemdir. Böylece Nobel Edebiyat Ödülü bağlamında sürdürülen polemikler, edebiyatın ve sanatın kriterlerini göz ardı eden kaba politik değerlendirmeler aşılacaktır. Çünkü küresel edebiyat eğilimi bağlamında verilen bir ödül, ancak küresel edebiyat eğiliminin argümanları ile tam olarak anlaşılabilir.

Hakem Değerlendirmesi: Dış bağımsız.

Çıkar Çatışması: Yazarlar çıkar çatışması bildirmemiştir.

Finansal Destek: Yazarlar bu çalışma için finansal destek almadığını beyan etmiştir.

Peer-review: Externally peer-reviewed.

Conflict of Interest: The authors have no conflict of interest to declare.

Grant Support: The authors declared that this study has received no financial support.

\section{KAYNAKÇA/REFERENCES}

Bermann, S. (2018). Karşılaştırmalı edebiyat ve dünya edebiyatı. (O. Tecimen, Çev.). Notos, 73, 27-37. Casanova, P. (2010). Dünya edebiyat cumhuriyeti (S. Özen ve F. Deniztekin, Çev.), İstanbul: Varlık Yayınları.

Damrosch, D. (2009). Orhan Pamuk ile söyleşi. Çakmak, E. E. (Ed.). Dünya Edebiyatı Deyince (s. 19-34). İstanbul: Varlık Yayınları.

Damrosch, D. (2016). Dünya edebiyatı nasıl okunmalı? (2. baskı). İstanbul: İstanbul Bilgi Üniversitesi Yayınları.

Demir, F. (2019). Elif Şafak'ın küresel romanı Araf'a tematik bir bakış. V. Uluslararası El Ruha Sosyal Bilimler Kongresi, Tunus.

Demir, F. ve Arvas, A. (2020). Küresel romanda üstopya söylemine bir örnek: Margaret Atwood'un Antilop ve Flurya adlı eseri. International Journal of Languages Education and Teaching, 8(3), 168-186.

Eagleton, T. (2005). Kültür yorumları (Özge Çelik, Çev.). İstanbul: Ayrıntı Yayınları.

Erdoğan, M. (2015). Küresel çağda çağdaş sanat ve küresel sanat pazarı, Anadolu Üniversitesi Sosyal Bilimler Dergisi, 15(1), 75-98.

Escarpit, R. (1968). Edebiyat sosyolojisi (A.T. Yazıcı, Çev.), İstanbul: Remzi Kitabevi.

Gürbilek, N. (2020). İkinci hayat (2. baskı). İstanbul: Metis Yayınları.

Kirsch, A. (2019). Küresel roman: 21. yüzyılda dünyayı yazmak (A. Yılmaz, Çev.), İstanbul: Vakıfbank Kültür Yayınları.

Küçükislamoğlu, Ü. (2014). Nobel Edebiyat Ödülü'nün yapısı ve dünya edebiyatındaki işlevi. (Yüksek Lisans). İstanbul Bilgi Üniversitesi, Sosyal Bilimler Enstitüsü, İstanbul. 
Meriç, C. (1998). Kırk ambar(I) rümuz-ül edeb. İstanbul: İletişim Yayınları.

Mufti, A. R. (2009). Şarkiyatçılık ve dünya edebiyatlarının kuruluşu. Çakmak, E. E. (Ed.). Dünya Edebiyatı Deyince (s. 193-210). İstanbul: Varlık Yayınları.

Parks, T. (2019). Ben buradan okuyorum: kitapların değişen dünyası (Roza Hakmen, Çev.). İstanbul: Metis Yayınları.

Tomlinson, J. (2017). Küreselleşme ve kültür (Arzu Eker, Çev.). İstanbul: Ayrıntı Yayınları.

Türk Dil Kurumu. (2011). Türkçe sözlük (genişletilmiş baskı). Ankara: Türk Dil Kurumu Yayınları.

Yıldırım, A. ve Şimşek, H. (2016). Sosyal bilimlerde nitel araştırma yöntemleri. https://ws1.turcademy. $\mathrm{com} /$ ww/webviewer.php?doc=21317 22.12.2020 tarihinde erişilmiştir.

The Nobel Prize. (2020). Statues of the Nobel Foundation. https://www.nobelprize.org/about/statutes-ofthe-nobel-foundation/\#par3 15.11.2020-30.11.2020 tarihleri arasında erişilmiştir.

Svenska Akademien. (2020). The Nobel Prize in Literature. https://www.svenskaakademien.se/en/thenobel-prize-in-literature 15.11.2020-30.11.2020 tarihleri arasında erişilmiştir. 
